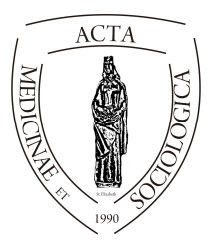

Acta Medicinae et

Sociologica (2020)

Vol. 11., Különszám. (5-17)

doi:

\title{
A sport, mint a depresszióval szembeni védőfaktor
}

\author{
Keczeli Danica
}

Klinikai- és sport szakpszichológus, oktató

Debreceni Sportcentrum- Sportiskola Kft., Debrecen 4032, Oláh Gábor u.5.

Debreceni Egyetem, Gazdasági Tudományi Kar, Sportgazdasági és -menedzsment Tanszék

Debrecen 4032, Böszörményi út 138.

\section{INFO ABSTRACT}

\section{Keczeli Danica \\ keczeli.danica@cts.hu}

\section{Keywords:}

leisures ports, competitive sports, depression, mental health

\begin{abstract}
The study examines the relationship between sport and depression among athletes in leisure and competition. A total of 436 people completed a questionnaire measuring the factors examined (Beck-Depression Questionnaire Abbreviated Version), of which 139 responders were leisure time athletes and 297 professional athletes. The aim of my study was to map out whether sport appeared as a protective factor for young people engaged in leisure sports, and whether the protective effect of sport on competitive athletes could prevail over the various symptoms of depression. Furthermore, whether there is a correlation between gender, education, occupation and consumption of legal drugs and depression.

From the results we can see that the depression value of athletes at competition level is higher than that of the athletes in leisure sports. In addition, I was able to experience a significantly higher depression value among the people aged between 18-20 than those aged 30 and over. I also found a significant difference in terms of gender in favour of women. People with a low level of education and those who do not have a full-time job have witnessed more depressive symptoms on themselves. By examining the consumption of legal drugs, I could show a correlation between alcohol and depression.
\end{abstract}

\section{Kulcsszavak:}

szabadidősport, versenysport, depresszió, mentális egészség
Absztrakt: [A tanulmány a sport és a depresszió összefüggéseit vizsgálja szabadidő- és a versenysportolók körében. A vizsgált faktorokat mérő kérdőívet (Beck-féle Depresszió Kérdőív rövidített változat) összesen 436 fö töltötte ki, ebből 139 szabadidősportoló és 297 versenysportoló volt. Vizsgálatom célja az volt, hogy a felmért mintán feltérképezzem, hogy a sport védő faktorként megjelenik-e a szabadidősporttal foglalkozó fiataloknál, illetve tud-e érvényesülni a sport védő hatása a versenysportolók körében is, a depresszió különböző tüneteivel szemben. Továbbá van-e összefüggés a 
nem, a végzettség, a foglalkozás és a legális szerek fogyasztása és a depresszió között.

A kapott eredményekböl látható, hogy a versenysportolók depresszió értéke tendenciájában nagyobb értéket mutat, mint a szabadidősportolóké. Továbbá a 18-20 éveseknél szignifikánsan magasabb depresszió érték tapasztalható, mint a 30 éveseknél és az afölöttieknél. Nemek tekintetében is jelentős eltérés mutatkozott, a nők javára. Az alacsony végzettségüek, valamint a nem teljes állásban foglalkoztatottak több depreszsziós tünetet észlelnek magukon. A legális szerek fogyasztását vizsgálva az alkohol és a depresszió között összefüggést tudtam kimutatni

\section{Bevezetés}

A rendszeres fizikai aktivitás, sportolás pozitív hatással van az egészségünkre. Elmondható, hogy a sport egyszerre egészségvédő, egészségfejlesztő és egészségmegőrző hatással bír. Egyaránt pozitív hatással van a fizikai és a mentális egészségre. A sportolás során olyan képességekre teszünk szert, amelyeknek az élet más területein is hasznát vehetjük. Sok helyen olvasható, hogy a sport segít a stresszel való megküzdésben. Ugyanakkor a versenysport esetében feltevődik a kérdés, hogy az eredmény-centrikusság, a „Citius, Altius, Fortius” (gyorsabban, magasabbra, erősebben) elv okozhat-e a versenysportolóknál stressz helyzetekből fakadó depressziót? A versenysportolók állandó stressznek vannak kitéve, a teljesítménykényszer és a megélt kudarcok hatással lehetnek a hangulatukra. Felmerül, hogy az ismétlődő kudarcok semlegesíthetik a sport jótékony hatását is. Ezek alapján vizsgálatom célja az volt, hogy a felmért mintán feltérképezzem, hogy a sport védő faktorként megjelenik-e a szabadidősporttal foglalkozó fiataloknál, illetve tud-e érvényesülni a sport védő hatása a versenysportolók körében is a depresszió különböző tüneteivel szemben.

\section{Szakirodalomi áttekintés}

Petrika (2012) értekezésében azt írja, hogy „amióta ember létezik, depresszió is van”. Korábban inkább a szomorúság, búskomorság, melankólia elnevezések fedték a ma depresszió alatt ismert érzelmi állapotot. Olyan létezés módról vagy negatív életminőségről van szó, amely az ember érzésvilágára, gondolataira és cselekvéseire egyaránt negatívan hat (Tringer 2003). Pervazív módon az egész személyiséget áthatja, az egyén világpercepcióját negatívan átszínezi, a mindennapi élethelyzetek és életesemények szubjektív megélését és azok minősítését lényegi módon negatív irányba elmozdítja (Petrika - PhD értekezés 2012; Popper et. al. 2014).

A depresszió levert lelkiállapotot jelent, mely hatására az egyén érzelmi életében egyensúlyvesztés történik, a gondolkodás lassúvá válik, ami következtében csökken az egyén aktivitási szintje, és mindezt testi tünetek is kísérik. A negatív és pesszimista 
életérzés az egész személyiséget és annak világnézetét is áthatja (Petrika 2012; Popper et. al. 2014).

A depresszió diagnosztikai kritériumai, DSM (DSM-IV, 2001) és BNO-10 (BNO10, 2004) szerint: a depressziós, szomorú hangulat; az érdeklődés és az örömkészség jelentős csökkenése; a testsúly csökkenése, vagy gyarapodása; az alvás igény csökkenése vagy fokozódása; az egyént nyugtalanság és gátoltság jellemzi; megjelenik a fáradtság, az erőtlenség és az értéktelenség, az önvád és a büntudat érzése; csökken a gondolkodási, a koncentrálási és a döntési képesség; megjelenik a céltalanság, a reménytelenség, vagy szuicid gondolatok illetve kísérletek.

A diagnózis felállításához a fent említett tünetek közül legalább öt egyidejű megjelenése szükséges, bár a tünetek megítélése nem könnyü feladat.

Abban az esetben, ha a klinikai diagnóziskritériumai nem teljesülnek, illetve a keletkező tünetek jóval enyhébb formában jelennek meg, vagy kevesebb a tünet, mint a "valódi" depresszió esetében, szubklinikusdepresszióról vagy minor depresszióról szokás beszélni (Szádóczky 2000).

A betegség kialakulásának lehetséges okai között szerepelnek biológiai okok, mint öröklött tényezők vagy genetikai adottságok. Ezek mellett fontosak a pszichoszocális tényezők, mint a társas támogatás hiánya, stresszhelyzeteknek való kitettség (Petrika 2012).

A depresszió forrása lehet az életkor, foglalkozás, végzettség vagy éppen a lakóhely, vagyis mindaz, ami az egyén életének szerves része és hatással van társadalmi helyzetére. Egyre inkább kénytelenek vagyunk beszélni a gyermekkori (!) és serdülőkori depresszióról is. Az idős korosztályoknál a depresszió gyakran inkább társul valamely betegséghez, vagy tartós testi baj kísérőjeként jelenik meg. A depresszió további gyakori okai az időseknél a fizikai és szociális izoláció, az egyre kisebb élettér, az elmagányosodás és célnélküliség, az értelmes elfoglaltság hiánya, a gyász és veszteségek (Petrika 2008; 2009).

A depressziós tünetegyüttes háttérében genetikai hatások állhatnak. Számos pszichológia elmélet különböző módon magyarázza a depresszió kialakulását (a tárgyvesztésre adott reakció vagy szociális készségek és önjutalmazó magatartások hiánya, vagy az információfeldolgozás sajátos zavara). A szociológia megfontolások szerint a depresszió mögött a gyakori stresszes életesemények, a kontrollvesztés és a krónikus stressz élménye áll (Tringer 2005).

A tartósan fennálló negatív stressz depresszióhoz vezethet, már fiatal korban is megjelenhet és társadalmunk egyre nagyobb részét érintheti.

A versenysportolók folyamatos stressznek vannak kitéve, így érthető, ha közöttük is előfordul a depresszió, annak ellenére, hogy aktív, sportos életet élnek. Számos kutatás szerint különösen előnyös hatással bír a rendszeres sportolás a depressziós állapotokra és tünetekre, valamint prevenciós és életminőség-védő és -megőrző eszközként is müködik (Petrika 2007).

A testedzés és a depresszió közötti kapcsolat kutatása igen régre nyúlik vissza. A testedzés hatékonyságát a depresszióval szemben számos kutatás igazolja. Az egészséges populációban a futók általában kevésbé depressziósak, mint a nem futók (Feist és Brannon 1988); az aerobikus testedzés terápiás eszközként sikeresen alkalmazható klinikai depresszióban szenvedő egyének kezelésében (pl. Sachs és Buffone 1984; Hannaford, Harrell és Cox 1988, idézi Detre 2007). Továbbá a rendszeres testmozgás 
befolyásolja az önbizalmat, vagy a pozitív gondolkodást (Baker és mtsai 2003; Kovács és Perényi 2012; Monge-Rojas és mtsai 2002,), vagy a depressziós tünetre hat (Pikó és Keresztes 2006; Kovács és mtsai 2014). Mindez összekapcsolható a sportolás közbeni endorfin szint növekedésével és a noradrenalin szint szabályozásával (Pikó és mtsai 1996; Siever és Davis 1985; idézi Barabásné és Keresztes 2017).

Martinsen (1989: idézi Hatfield 1991) miután áttekintette az 1980-89 között publikált szakirodalmakat, amelyekben a testmozgás-program hatását vizsgálták szorongásos és/vagy depressziós személyeknél, azt találta, hogy egyértelmú a testmozgás antidepresszáns és szorongáscsökkentő hatása.

Mivel a sport általában társaságban üzhető tevékenység és a személyiségre feltöltő hatással bír, különböző sportjátékokat terápiás módszerként alkalmaznak számos kórházi osztályon a depresszió elleni küzdelemben. Bizonyítottan csökkenthetők az antidepresszáns gyógyszerek dózisai, esetleg el is hagyhatók ezen programok alkalmazásával. Függetlenül a sportág jellegétől (egyéni, csoportos, aerob, anaerob testedzés) a rendszeres sportolás nem csak terápiás módszerként alkalmazható, hanem a legfontosabb preventív eszköznek is tekinthető a mentális és fizikai egészség megőrzésében. A sport egészségmegőrző hatása abban is érvényesül, hogy számos betegség megelőzhető a sport segítségével, mint szívizom infarktus, magas vérnyomás betegség, elhízás betegség, stressz okozta bélrendszeri betegség, cukorbetegség stb. (Honfi et. al. 2009). Köztudott és vizsgálatokkal bizonyított, hogy ezek a testi betegségek közvetlen vagy közvetett módon szerepet játszhatnak a depresszió kialakulásánál.

Végül a rendszeres testmozgás hozzájárulhat a társas kapcsolatok kialakításához és fenntartásához, amivel elkerülhető a szociális izoláció, mint rizikó faktor, és gyakran a csapattárs erős motivációként hathat a testmozgás folytatásában.

A rendszeres edzések védő faktorként jelennek meg személyiségfejlődésnél, emelkedik a pozitív énkép kialakulásának a valószínüsége, valamint növekszik az önbizalom, az élettel való elégedettség, a nyitottság és az optimizmus. Azok körében, akik nem sportolnak nagyobb az esélye a negatív énkép kialakulásának és olyan depreszsziós tünetek megjelenésének, mint unalom, céltalanság, szorongás és reménytelenség (Barabasné és Keresztes 2017).

Aktív sportolói pályafutásom során, és később sportpszichológusi munkásságom során számos olyan versenysportolóval találkoztam, akiken időként észrevehetőek a depresszió tünetei. A folyamatos eredménykényszer komoly stressz forrása lehet a sportolók életében és ebből kifolyólag a várható eredmény elmaradása jelentős mértékben befolyásolhatja a sportoló hangulatát, elterelheti a figyelmét a teljesítményről az érzelmi állapotára, ami okozhatja a teljesítmény romlását, ami újabb kudarcok forrása lehet. Ezen mechanizmus mentén, ha nem kap megfelelő segítséget, a versenysportoló akár hosszabb ideig produkálhat különböző depresszív tüneteket.

A kutatásomban két csoportot, a szabadidő- és a versenysportolókat hasonlítottam össze, illetve esetükben vizsgáltam a sport szerepét. Kutatási koncepcióm szerint feltételezem, hogy különösen a szabadidő-sportolók esetében igazolható a sport jótékony hatása a mentális egészségre, illetve ezzel szemben a versenysportolók esetében az állandó teljesítménykényszer miatt azt feltételezem, hogy náluk a depressziós tünetek fokozottabban vannak jelen. Továbbá feltételezem, hogy a korábbi hasonló kutatások eredményeivel (Jang et. al. 2007; Storch et. al. 2005; Silverstein1999; Hammond et. 
al. 2013) összhangban a nők több depressziós tünetet produkálnak, mint a férfiak. Vizsgáltam még, hogy van-e összefüggés a nem, a végzettség, a foglalkozás és a legális szerek fogyasztása és a depresszió között.

\section{Anyag és módszer}

Kutatásomban a sport és a depresszió összefüggéseit vizsgáltam a fiatal felnőtteknél. A vizsgálatom alapját az általam készített on-line kérdőív adta.

\begin{tabular}{|l|c|c|c|c|}
\hline Minta & Férfi & Nö & N & \% \\
\hline Szabadidősportoló & 50 & 89 & 139 & $32 \%$ \\
\hline Versenysportoló & 133 & 164 & 297 & $68 \%$ \\
\hline Összes & $\mathbf{1 8 3}$ & $\mathbf{2 5 3}$ & $\mathbf{4 3 6}$ & \\
\hline Minta eloszlása \%-ban & $42 \%$ & $58 \%$ & & $100 \%$ \\
\hline
\end{tabular}

Forrás: Saját szerkesztés

1. táblázat. A minta nem és a sportolási szint szerinti megoszlása (\%)

A minta nagysága 436 fö ( $\mathrm{N}=436$ ), ebből 253 fő (58 \%) nő és 183 fö (42\%) férfi. Az összesített adatok alapján a minta 32\%-a szabadidősportolónak, míg a minta $68 \%$-a versenysportolónak nevezte magát (1. Táblázat).

A megkérdezettek 13,5\%-a 18 év alatti, 25,3\%-a 18-20 közötti, 25,4\%-a 21-23 év közöttiek, 20,9\%-a 24-29 év közöttiek és 14,9\%-a 30 éves, és afölötti. A megkérdezettek 48,2 \%-a tanuló, 43,6\%-a dolgozó és 8,2\%-uk az egyéb kategóriát jelölte meg, azaz nem tanul, és nem teljes munkaidőben foglalkoztatott. A végzettségek tekintetében a minta 24,8\%-a alapfokú, 50,2\%-a középfokú és 25\%-a felsőfokú végzettséggel bír. A megkérdezettek 75\%-a átlagos anyagi helyzetben látja magát, míg a fennmaradó 4,8\%-a átlag alatti, illetve 20,2\%-a átlag feletti anyagi helyzetben van.

A kérdőív felvétele egyrészt internetes hálózatok útján, másrészt a különböző iskolák és sportszervezeteket, sportklubok személyes megkeresésével történt. A teljes kérdöív kitöltése 12-14 percet vett igénybe. A teljes kérdőív egyrészt szociodemográfiai változókat, másrészt nyolc standardizált és megbízható mérőeszközt foglal magában. Jelen tanulmányban a sport és a depresszió összefüggését, a szociodemográfiai változók (kor, iskolai végzettség, foglalkozás, anyagi háttér) kapcsolatát a depresszió tüneteivel, továbbá a minta dohányzás és alkohol fogyasztási szokásait elemzem.

Az esetleges hangulatzavar (depresszió) feltárásához más kutatók (Rózsa et. al. 2001) által számos epidemiológiai vizsgálat során használt Beck-féle Depresszió Kérdőív rövidített, 9 tételes, 4-fokú Likert-skálát (egyáltalán nem jellemző/ kicsit jellemző/ majdnem jellemző/ teljes mértékben jellemző) tartalmazó mérö eszközét alkalmaztam, mely önjellemzésén alapul és amelyben az egyes tételek kitöltésével a válaszadók kifejezhették mennyire jellemző rájuk az adott állítás (a magasabb pontszám a depressziós tünetek fokozottabb előfordulását jelzi).

A mérőeszköz tételei: a szociális visszahúzódás (közönyösség), a döntésképtelenség, az alvászavar, a fáradékonyság, a testi tünetek miatti túlzott aggódás (hipochondria), 
a munkaképtelenség, az elégedetlenség és az örömképesség hiánya, a pesszimizmus és az önvádlás (Susánszky - PhD értekezés, 2009).

A skálán elérhető maximális pontszáma 36. Ezen belül 0-9 pont - nincs depressziós tünetegyüttes, 10-18 pont - enyhe depressziós tünetegyüttes, 19-25 pont - közepesen súlyos depressziós tünetegyüttes, és 25 pont fölött - súlyos depressziós tünetegyüttes jelenlétét mutatja. A súlyos depressziós tünetegyüttes kritériumai a major depresszió klinikai kritériumainak felelnek meg.

Teszteltem a kutatás során felhasznált kérdőív megbízhatóságát. A kérdőív Cronbachalpha értéke alapján az alkalmazott eszköz megbízhatónak minősül $(\alpha=0,85)$.

A statisztikai adatok elemzése SPSS 25.0 statisztikai szoftverrel történt, a leíró statisztika mellett ANOVA és Tukey próba lefuttatására is sor került. A statisztikai próbák eredményeit $\mathrm{p}<0,05$ esetén tekintettem szignifikánsnak.

\section{Eredmények}

A teljes minta depresszió értéke 12,21. A nők átlag értéke 11,87 a férfiaké pedig 12,68, ami az enyhe depressziós tünetegyüttes kategóriába esik. A szabadidő-sportolók körében a depresszió átlag értéke 11,94, míg a versenysportolók körében a depresszió átlag értéke 12,34, azaz mindkét sportolói csoport enyhe depressziós tüneteket tulajdonít magának (2. táblázat).

\begin{tabular}{|c|c|c|c|c|c|c|c|c|c|c|c|}
\hline \multicolumn{2}{|c|}{$\begin{array}{c}\text { Nők } \\
(\mathrm{N}=253)\end{array}$} & \multicolumn{2}{|c|}{$\begin{array}{c}\text { Férfi } \\
(\mathrm{N}=183)\end{array}$} & \multicolumn{2}{|c|}{$\begin{array}{c}\text { Szabadidős } \\
(\mathrm{N}=139)\end{array}$} & \multicolumn{2}{|c|}{$\begin{array}{l}\text { Versenysportolók } \\
\qquad(\mathrm{N}=297)\end{array}$} & \multicolumn{4}{|c|}{ Teljes minta $(\mathrm{N}=436)$} \\
\hline Átlag & $\begin{array}{l}\text { Szó- } \\
\text { rás }\end{array}$ & Átlag & $\begin{array}{c}\text { Szó- } \\
\text { rás }\end{array}$ & Átlag & $\begin{array}{c}\text { Szó- } \\
\text { rás }\end{array}$ & Átlag & & Átlag & $\begin{array}{l}\text { Szó- } \\
\text { rás }\end{array}$ & & $\begin{array}{l}\text { Cronbac } \\
\text { alfa }\end{array}$ \\
\hline 11,87 & 3,8 & 12,68 & 5,07 & 11,94 & 4,0 & 12,34 & 4,6 & 12,21 & 4,4 & 9 & 0,852 \\
\hline
\end{tabular}

Forrás: Saját szerkesztés

2. táblázat. Beck-féle Depresszió Kérdőív leíró adatai a mintában $(\mathrm{N}=436)$

A teljes minta tekintetében szignifikáns különbség $(\mathrm{p}=0,02)$ van a nemek között, a nők javára. A férfi mintánál szignifikánsan magasabb értékek figyelhetők meg a depresszió esetében. A versenysportolók és a szabadidősportolók esetében tendencia szintü különbség tapasztalható, a versenysportolók esetében magasabb a depresszió átlagértéke $(0,17)$ (3. táblázat).

Forrás: Saját szerkesztés

\begin{tabular}{|l|l|l|l|}
\hline & & Átlag & Szórás \\
\hline \multirow{2}{*}{ Nök } & Szabadidősportolók & 11,73 & 0,46 \\
\cline { 2 - 4 } & Verseny sportolók & 11,95 & 0,34 \\
\hline \multirow{2}{*}{ Férfiak } & Szabadidősportolók & 12,30 & 0,62 \\
\cline { 2 - 4 } & Verseny sportolók & 12,82 & 0,38 \\
\hline
\end{tabular}

3. táblázat. A Beck-féle Depresszió Kérdőív átlaga és szórása az egész mintán $(\mathrm{N}=436)$ 


\begin{tabular}{|l|c|c|c|}
\hline Korosztály & N & Átlag & Szórás \\
\hline 18 alatti & 59 & 13,34 & 5,57 \\
\hline $18-20$ év közötti & 110 & 12,73 & 4,86 \\
\hline $21-23$ év közötti & 111 & 12,40 & 4,11 \\
\hline $24-29$ év közötti & 91 & 11,56 & 3,98 \\
\hline 30 év és e fölött & 65 & 10,92 & 2,68 \\
\hline
\end{tabular}

Forrás: Saját szerkesztés

4. táblázat. A Beck-féle Depresszió Kérdőív korosztályok szerinti átlaga és szórása a szabadidő- és versenysportolók körében

A teljes minta tekintetében a korosztályok közötti különbség kimutatható volt, valamint az ANOVA F tesztjének eredménye is szignifikáns volt $(\mathrm{p}=0,01)$. A TUKEY post-hoc teszt alapján a 18 év alattiak depresszió értéke jelentősen eltért a 30 év és e fölöttiektől $(\mathrm{p}=0,02)$. Továbbá a 18-20 év közöttiek depresszió értéke tendencia szinten meghaladta a 30 év és e felettiek értékét $(p=0,06)$ (4. táblázat).

Az iskolai végzettség alapján végzett vizsgálatban az összes megkérdezett esetében az alapfokú végzettséggel rendelkezőknek jelentősen nagyobb depressziós átlagértéke volt, mint a másik két kategóriába tartozóknak (ANOVA F=9, 03; szf.: 2; 433 $\mathrm{p}<0,001)$.

\begin{tabular}{|l|c|c|c|}
\hline Végzettség & $\mathrm{N}$ & Átlag & Szórás \\
\hline Alap & 108 & 13,55 & 5,26 \\
\hline Középfokú & 219 & 12,12 & 4,38 \\
\hline Felsö & 109 & 11,07 & 2,89 \\
\hline
\end{tabular}

Forrás: Saját szerkesztés

5. táblázat. A Beck-féle Depresszió Kérdőív átlaga és szórása az iskolai végzettség tekintetében az egész mintán ( $\mathrm{N}=436)$

A végzettség tekintetében külön vizsgáltam a szabadidő- és külön a versenysportolókat és a következő eredményeket kaptam: a szabadidősportolók körében a különböző végzettséggel rendelkezők csoportjai között tendencia szintü eltérés mutatható ki (ANOVA F = 2,94 szf.: 2; $136 \mathrm{p}=0,06$ ). A versenysportolók körében a csoportok között szignifikáns különbséget (ANOVA F=6,01 szf.: 2; $294 \mathrm{p}=0,003$ ) találtam. A TUKEY post-hoc teszt alapján megállapítottam, hogy az alapfokú és a középfokú, valamint az alapfokú és a felsőfokú végzettséggel rendelkezők szignifikáns mértékben különböznek egymástól, a magasabb végzettségüek javára.

A megkérdezettek foglalkozásának elemzésekor az összes megkérdezett esetében a nem tanuló és teljes munkaidőben nem foglalkoztatottak jelentősen nagyobb depressziós átlagértéket mutattak, mint dolgozók vagy tanulók (ANOVA F= 5,13 szf.: 2; $433 \mathrm{p}=0,006$ ). 


\begin{tabular}{|l|c|c|c|}
\hline & $\mathrm{N}$ & Átlag & Szórás \\
\hline Dolgozó & 190 & 11,49 & 3,99 \\
\hline Tanuló & 210 & 12,66 & 4,43 \\
\hline Egyéb & 36 & 13,42 & 5,55 \\
\hline
\end{tabular}

Forrás: Saját szerkesztés

6. Táblázat: A Beck-féle Depresszió Kérdőív átlaga és szórása foglalkozás tekintetében az egész mintán $(\mathrm{N}=436)$

A foglalkozás tekintetében külön vizsgáltam a szabadidő- és külön a versenysportolókat és a következő eredményeket kaptam: a különböző foglalkozási csoportok között szignifikáns különbség volt kimutatható mind a szabadidősportolók körében (ANOVA F =7,11 szf::2; 136 p=0,001), mind a versenysportolók körében (ANOVA $\mathrm{F}=3,53$ szf:: $2 ; 294 \mathrm{p}=0,03)$.

A legális szerek (alkoholfogyasztás és dohányzás) és a depresszió összefüggését vizsgálva az összes megkérdezett esetében csak az alkoholfogyasztásnál mutatható ki marginális szignifikáns eltérés (ANOVA F = 2,77 szf.: 2; $433 \mathrm{p}=0,06$ ).

Alkoholfogyasztás esetében azok a megkérdezettek, akik elmondásuk szerint egyáltalán nem isznak, vagy majdnem mindennap isznak alkoholt nagyobb depresszió értéket mutattak, mint azok, akik ritkán, havonta egyszer vagy hetente egyszer fogyasztanak alkoholt (7. táblázat).

\begin{tabular}{|l|c|c|c|}
\hline & N & Átlag & Szórás \\
\hline Nem isznak & 93 & 13,05 & 5,09 \\
\hline Csak egyszer havonta vagy hetente & 262 & 11,84 & 3,90 \\
\hline Majdnem mindennap & 81 & 12,44 & 4,88 \\
\hline
\end{tabular}

Forrás: Saját szerkesztés

7. táblázat: Depresszió átlaga és szórása az alkoholfogyasztás fényében

Függetlenségvizsgálat segítségével ellenőriztem, hogy a legális szerek használatában van-e különbség a versenysportolók és a szabadidősportolók között. A kapott eredmények alapján elmondható, hogy a dohányzás esetében szignifikáns különbséget tapasztaltam szabadidő- és versenysportolók között $\left(\chi^{2}=7,85\right.$ szf::2 436 p=0,02). A szabadidősportolók 36,7\%-a, a versenysportolók pedig 49,2\%-a soha nem dohányzott. Míg a szabadidősportolók 39,6\%-a alkalmanként (hetente egyszer) dohányzik, addig a versenysportolóknál ez a szám 36,0\%. Végül a szabadidősportolók 23,7\%-a, míg versenysportolók 14,8 \%-a dohányzónak jelölte magát (8.táblázat).

\begin{tabular}{|c|l|c|c|c|}
\hline & & Nem dohányzik & Alkalmanként & Naponta \\
\hline \multirow{2}{*}{ Dohányzás } & Szabadidősportoló & $36,7 \%$ & $39,6 \%$ & $23,7 \%$ \\
\cline { 2 - 5 } & Versenysportoló & $49,2 \%$ & $36,0 \%$ & $14,8 \%$ \\
\hline
\end{tabular}

Forrás: Saját szerkesztés

8. táblázat: Dohányzási szokások szabadidő- és versenysportolók körében 
Az alkoholfogyasztás esetében a különbség tendencia-szinten jelentkezett $\chi^{2}=4,82$ szf.:2 436 p=0,09). A szabadidősportolók 24,5\%, míg a versenysportolók 15,8 \%-a majdnem mindennap alkoholt fogyaszt. Tehát elmondható, hogy a versenysportolókra jellemzőbb a mértéktartás (9. táblázat).

\begin{tabular}{|l|l|l|l|l|}
\hline & & Nem iszik & Havonta & Majdnem mindennap \\
\hline Alkoholfogyasztás & Szabadidősportoló & $18,7 \%$ & $56,8 \%$ & $24,5 \%$ \\
\cline { 2 - 5 } & Versenysportoló & $22,6 \%$ & $61,6 \%$ & $15,8 \%$ \\
\hline
\end{tabular}

Forrás: Saját szerkesztés

9. Táblázat: Alkoholfogyasztási szokások \%-ban szabadidő- és versenysportolók körében

\section{Megbeszélés}

A sportvilágban széles körben elterjedt feltételezés, hogy csak érzelmileg és szellemileg erős sportolók tudnak teljesíteni a legmagasabb szinten (Hammond et. al., 2013). A versenysportolók körében ritkán fordul elő a depresszió, mint pszichológiai rendellenesség. Jelen tanulmány azonban ettől eltérő eredményeket mutat.

Részben meg tudom erősíteni azon feltételezésemet, miszerint a versenysport olyan stresszel jár együtt, ami a depressziós tünetek fokozottabb jelenlétét idézi elő a versenysportolóknál. A szabadidősportolók körében a depresszió átlag értéke alacsonyabb volt, mint a versenysportolóké, bár mindkét csoport az enyhe depressziós tünetegyüttes kategóriába esett, ami utalhat arra, hogy a versenysportolók fokozottan veszélyeztetve lehetnek a depresszióval szemben. A folyamatos kihívások, mint például a gyakori versenyhelyzetek, a teljesítménnyel járó nyomás, a média állandó figyelme és a bekövetkező kudarcoktól való félelem kétségtelenül pszichopatológiai formában jelentkezhetnek (Hammond et. al., 2013). A mai versenysportolók hatalmas fizikai, társadalmi és pszichológiai nyomás alatt állnak (Hammond et. al., 2013; Markser, 2011).

Tanulmányomban a depresszió és a nemek közti összefüggésben szignifikáns különbséget mutattam ki a férfiak és a nők között, a nők javára, ami nem egyezik meg más kutatásokban kapott eredményekkel (Hammond et. al., 2013). A depresszió elöfordulásának korábbi eredményeivel ellentétben (Yang et. al., 2007; Storch et. al., 2005; Silverstein, 1999; Hammond et. al., 2013) jelen kutatás megállapította, hogy szignifikánsan több sportban aktív férfi, mint sportban aktív nő találkozik a depressziós betegség diagnosztikai kritériumaival. Ez az eredmény arra enged következtetni, hogy a teljesítménybeli elvárás a férfiak számára nagyobb terhelés, míg a nők esetében vannak olyan tényezők, amelyek fokozottan csökkenthetik a depressziót: például a női sportolók általában könnyebben kérnek segítséget és hamarabb jelzik negatív tüneteiket szakembernek (Markser, 2011). A nemek közti eltérések kapcsolatba hozhatók a fiúk és a lányok eltérő sportmotivációjával (Pikó et. al., 2004) is, miszerint a lányokra sokkal inkább jellemző, hogy azért sportolnak, hogy csinosak, egészségesek legyenek, míg a fiúk gyakran a versenyzés kedvéért, az erejük demonstrálásáért, illetve a győzelemre való törekvés kedvéért sportolnak (Finkenberg, 1991; Koivula, 1999). 
Megállapítható, hogy további kutatások szükségesek ahhoz, hogy megértsük, hogy a férfi, illetve női sportolók esetében mi az, ami fokozza a depresszió kockázatát. Egyre fontosabbá válnak a szubjektív, saját értékelésen alapuló mutatók, a saját fizikai és mentális egészségi állapot jellemzése, illetve az egészség megtartásának módja is egyre fontosabb. Ezen ismeretek alapján a szürési eljárásokat és a támogatási rendszereket is fejleszteni kell.

A teljes minta tekintetében a fiatalabb korosztály szignifikánsan depresszívebb, mint a 30 évesek és afölöttiek, ami magyarázható a fiatalabb korosztály életszakaszához illeszkedő problémáival. A 18-23 évesek éppen az „élet legfontosabb kérdéseivel” vannak elfoglalva, azaz azzal, hogy sportolói vagy „civil” karriert válasszanak, hogyan alakítsanak ki párkapcsolatot, családot, milyen lesz a felnőtt életük. Míg a 30 évesek és afölöttiek nagyobb részt már döntöttek ezekben a kérdésekben, már választottak lehetséges életutat.

Az iskolai végzettség és a depressziós tünetek előfordulásával kapcsolatban a korábbi kutatásokkal összhangban (Boros et. al., 2018) kimutattam, hogy az alacsony végzettségüek szignifikánsan depresszívebbek, mint a közép- vagy felsőfokú végzettségü társaik.

Szintén szignifikánsan depresszívebbek a teljes minta, valamint a szabadidő- és a versenysportolók esetében a nem tanuló, és nem teljes munkaidőben foglalkoztatottak (diákmunka, részmunka, gyes, gyed, stb.), mint azok, akik tanultak vagy dolgoztak. Ez az említett csoport bizonytalanságával, anyagi függőségével jól magyarázható.

Végül a legális szerek (alkoholfogyasztás és dohányzás) és depresszió összefüggésének tekintetében az összes megkérdezett esetében csak az alkoholfogyasztásnál találtam marginális szignifikáns eltérést. Azonban a legális szerek fogyasztásában, mind a dohányzás, mind az alkohol tekintetében a versenysportolók egészségesebb magatartást tanúsítottak. Ez egybecseng azokkal a kutatásokkal, ahol a sportról, mint egészségmegtartó tevékenységről írnak, arról, hogy a rendszeresen sportoló fiatalok életmódja egészségtudatosabb (pl. kevesebbet dohányoznak (Burke et. al., 1997)). Ugyanakkor akadnak olyan vizsgálatok is, amelyek nem találtak egyértelmüen pozitív összefüggést a sport és a legális szerek (alkohol, dohányzás) fogyasztása (Faurie et. al., 2004), illetve a sport és az egészséges életmód között (Keresztes - Pikó, 2008).

\section{Összefoglalás}

Kutatásomban a szabadidő- és versenysportolók körében vizsgáltam, hogy a sport védőhatása érvényesül-e depresszióval szemben. Összegző eredményként megállapítható, hogy a versenysportolók fokozottan veszélyeztetve lehetnek a depresszióval szemben. Ez a megállapítás két oldalról is alátámasztható: Egyrészt a WHO (World Health Organization) közleményében olvasható, miszerint 2020-ra a szív- és érrendszeri megbetegedések után a depresszió válik majd a második munkaképesség-csökkenést okozó betegséggé (I-2); Másrészt, a versenysportban megjelenő fizikai, társadalmi és pszichológiai terhelés következtében, a versenysport összefonódik a krónikus stressz jelenségével, ami köztudottan veszélyezteti az egészséget. 
Mindezek ellenére a sportolás jótékony hatása nem kérdőjelezhető meg! Ez azonban versenysportban csak akkor tud érvényesülni, ha tudatosabban történik a versenysportolók fejlesztése, versenyeztetése, a versenyek ideje alatti és a versenyek közötti rehabilitációja. Javasolandó minden eszköz, módszer és szakember alkalmazása, amivel a fizikai és pszichés megterheltség mellett megőrizhető a sportoló fizikai és mentális egészsége.

A publikáció elkészitését a EFOP-3.6.2-16-2017-00003 Sport-Rekreációs és Egészséggazdasági Kooperációs Kutatóhálózat létrehozása projekt támogatta.

\section{Felhasznált irodalom}

1. Barabásné, K. D., Keresztes, N. (2017): Szubjektív jóllét a sportolási gyakoriság tükrében in Magyar Sporttudományi Szemle 18.évfolyam 69. szám. 2017/1. 4-9.

2. Boros, J., Györke, J., Pásztorné, S. E., Szabó, Zs. K. (2018): A 2014-ben végrehajtott európai lakossági egészségfelmérés eredményei In Tokaji, K. (szerk.): Összefoglaló adatok, Központi Statisztikai Hivatal, 2018 ISBN 978-963-235506-10̈ ISBN 978-963-235-508-5

3. BNO-10 zsebkönyv. DSM-IV-TR meghatározásokkal. Animula. ISBN 963-94106-16. Budapest, 2004

4. Burke, V., Milligan, R., Beilin, LJ., Dunbar, D., Spencer, M., Balde, E., Gracey, M.P. (1997): Clustering of Health-Related Behaviors among 18-Year-Old Australians. Prev Med, 26: 724-733. DOI: https://doi.org/10.1006/pmed.1997.0198

5. Detre, Z. (2007): Sporttal a stressz, a szorongás és a depresszió ellen. Oktatás, Nevelés, 29-49.

6. DSM-IV text revision. A módositott DSM-IV. Animula. ISBN 963-861-15-45. Budapest, 2001

7. Culbertson FM. (1997): Depression and gender. An international review. Am Psychol. 1997;52:25-31 DOI: https://doi.org/10.1037/0003-066x.52.1.25

8. Faurie C, Pontier D, Raymond M. (2004): Student athletes claim to have more sexual partners than other students. Evol Hum Behav, 25: 1-8. DOI: https://doi.org/10.1016/s1090-5138(03)00064-3

9. Finkenberg ME. (1991): Sex and ethnicity as factors for participation in physical activity. Int J Phys Educ, 28: 23-26.

10. Hammond et al (2013): The Prevalence of Failure-Based Depression Among Elite Athletes. In Clin J Sport Med 273-277. 2013 DOI: https://doi.org/10.1097/jsm.0b013e318287b870

11. Hatfield B. D. (1991): Exercise and mental health: The mechanism of exerciseinduced Psychological states. In: Diamant L. (Ed.) Psychology of sport, exercise and fitness. Social and personal issues. Hemisphere Publishing Corporation, New York, 1991, 17-49. o.

12. Honfi, L. (2009): A sport és a hétköznapok kapcsolata. Sport, életmód, egészség, (szerk.: Szatmári Zoltán), Budapest, Akadémiai Kiadó, 926-937. o.

13. Honfi, L., Szalay, G., Váczi, P. (2009): A sport beépülése a mindennapokba. Acta Academiae Agriensis, Sectio Sport, 2009. Nova series tom. XXXVI. pp.51-63. 
14. Keresztes, N., Pikó, B. (2008a): Fiatalok sportolási és táplálkozási szokásainak összefüggései. Magyar Sporttudományi Szemle, 9: 14-19.

15. Koivula, N. (1999): Sport participation: Differences in motivation and actual participation due to gender typing. J Sport Behav, 22: 360-380.

16. Lackó, T., Melczer, Cs., Cselik, B., Kovácsné, B. V., Kiss, G. (2015): Egészségsport alapjai. Pécsi Tudományegyetem Egészségtudományi Kar, Pécs, 200p.

17. Markser, V. Z. (2011): Sport psychiatry and psychotherapy. Mental strains and disorders in professional sports. Eur Arch Psychiatry Clin Neurosci. 2011;261:14. DOI: https://doi.org/10.1007/s00406-011-0239-X

18. Petrika, E. (2002): Mozgásterápia hatása kórházi depressziós betegeknél. SE 4. sz. Doktori Iskola Tudományos Ülés Absztrakt kötet, Budapest

19. Petrika, E. (2007): Prevenció vagy terápia? Testedzés szerepe a mentális egészség fenntartásában. „Tudomány a sportoló nemzetért” Konferenciasorozat 2007. Elöadáskivonatok. Konferencia kötet és CD. ÖM, Budapest. 56-60p.

20. Petrika, E. (2008): Testmozgás és sportolás idöskorban. In: Semsei Imre (föszerk.): Gerontológia. Debreceni Egyetem Egészségügyi Kari Jegyzetek 15. 518526 p. Nyíregyháza

21. Petrika, E. (2009): Testmozgás és mentális egészség idős korban: a depresszió." Gerontológiai körkép 2009” Nyíregyházi Gerontológiai Napok II. 2009. november 27-28. Az előadások összefoglalói

22. Petrika, E. (2012): Rendszeres testedzés hatása a mentális egészségre és az életminőségre fiatal felnöttként: depressziv tünetek, stressz és stresszkezelés összefüggéseinek empirikus vizsgálata, Egyetemi doktori értekezés, Debreceni Egyetem, Humán Tudományok Doktori Iskola.

23. Pikó, B., Keresztes, N. (2007): Serdülők egészségmagatartása két szociális megküzdési (coping) mechanizmus tükrében. Magyar Pszichológiai Szemle. 62. 203214 DOI: https://doi.org/10.1556/mpszle.62.2007.2.4

24. Pikó, B., Pluhár, Zs., Keresztes, N. (2004): Külső kényszer vagy belső hajtóerő? Gyermekek és serdülök fizikai aktivitásának motivációs tényezői. Alkalmazott Pszichológia, 3: 40-54.

25. Popper, P., Rihmer, Z., Tringer, L. (2014): Rosszkedv, szomorúság, depresszió. Sziget Könyvkiadó, Budapest, 175p.

26. Rózsa, S., Szádóczky, E., Füredi, J. (2001): A Beck Depresszió Kérdöív röviditett változatának jellemzői hazai mintán. Psychiatria Hungarica, 16 (4): 379-397.

27. Szádóczky, E., Rihmer, Z. (szerk) (2001): Hangulatzavarok. Medicina Könyvkiadó. Rt, Budapest

28. Silverstein, B. (1999): Gender difference in the prevalence of clinical depression: the role played by depression associated with somatic symptoms. Am J Psychiatry. 1999; 156:480-482.

29. Storch, E. A., Storch, J. B., Killiany, E. M. et al. (2005): Self-reported psychopathology in athletes: a comparison of intercollegiate student-athletes and non-athletes. J Sport Behav. 2005; 28:86-98.

30. Susanszky, É (2009): A magyar fiatalok életminőségének alakulása az elmúlt két évtizedben. Egyetemi doktori értekezés. Semmelweis Egyetem. Mentális Egészségtudományok Doktori Iskola. 
31. Tringer, L. (2003) Egészség és életminőség. Psychiatria Hungarica, 18(1), 2003, 10-16.

32. Tringer, L. (2005) A pszichiátria tankönyve. Semmelweis Kiadó. Budapest. ISBN 9639214477

33. Yang, J., Peek-Asa, C., Corlette, J. et al. (2007): Prevalence of and risk factors associated with symptoms of depression in competitive college student athletes. Clin J Sport Med. 2007;17:481-487. DOI: https://doi.org/10.1097/jsm.0b013e31815aed6b 